\title{
Opto-thermal technologies for microscopic analysis of cellular temperature-sensing systems
}

\author{
Kotaro Oyama ${ }^{1,2} \cdot$ Shuya Ishii ${ }^{1,3} \cdot$ Madoka Suzuki $^{4}$
}

Received: 30 August 2021 / Accepted: 12 October 2021 / Published online: 3 November 2021

(c) The Author(s) 2021

\begin{abstract}
Could enzymatic activities and their cooperative functions act as cellular temperature-sensing systems? This review introduces recent opto-thermal technologies for microscopic analyses of various types of cellular temperature-sensing system. Optical microheating technologies have been developed for local and rapid temperature manipulations at the cellular level. Advanced luminescent thermometers visualize the dynamics of cellular local temperature in space and time during microheating. An optical heater and thermometer can be combined into one smart nanomaterial that demonstrates hybrid function. These technologies have revealed a variety of cellular responses to spatial and temporal changes in temperature. Spatial temperature gradients cause asymmetric deformations during mitosis and neurite outgrowth. Rapid changes in temperature causes imbalance of intracellular $\mathrm{Ca}^{2+}$ homeostasis and membrane potential. Among those responses, heat-induced muscle contractions are highlighted. It is also demonstrated that the short-term heating hyperactivates molecular motors to exceed their maximal activities at optimal temperatures. We discuss future prospects for opto-thermal manipulation of cellular functions and contributions to obtain a deeper understanding of the mechanisms of cellular temperature-sensing systems.
\end{abstract}

Keywords Microscopy $\cdot$ Optical microheating $\cdot$ Temperature sensitivity $\cdot$ Temperature gradient $\cdot$ Thermometry

\section{Introduction}

Sensing the temperature is an essential activity for life. Humans sense a variety of temperatures of air, water, and food in their daily lives, such as sauna $\left(\sim 100{ }^{\circ} \mathrm{C}\right)$, hot tea $\left(\sim 60^{\circ} \mathrm{C}\right)$, comfortable shower $\left(\sim 40^{\circ} \mathrm{C}\right)$, iced coffee $\left(\sim 4^{\circ} \mathrm{C}\right)$,

Kotaro Oyama and Shuya Ishii contributed equally to this work.

Kotaro Oyama

oyama.kotaro@qst.go.jp

$\bowtie$ Madoka Suzuki

suzu_mado@protein.osaka-u.ac.jp

1 Quantum Beam Science Research Directorate, National Institutes for Quantum Science and Technology (QST), 1233 Watanukimachi, Takasaki, Gunma 370-1292, Japan

2 PRESTO, Japan Science and Technology Agency, 4-1-8 Honcho, Kawaguchi, Saitama 332-0012, Japan

3 Quantum Life and Medical Science Directorate, National Institutes for Quantum Science and Technology (QST), 4-9-1 Anagawa, Inage, Chiba 263-8555, Japan

4 Institute for Protein Research, Osaka University, 3-2 Yamadaoka, Suita, Osaka 565-0871, Japan and ice cream $\left(\sim-10^{\circ} \mathrm{C}\right)$. We also sense our own internal temperature to maintain our body temperature. If the temperature-sensing system is dysfunctional, we cannot predict threats such as thermal injury and hypo- and hyperthermia.

It has been shown that living organisms are equipped with various different temperature sensors at the cellular level. The well-known temperature sensors are the thermo transient receptor potential (TRP) channels, which are the temperature-sensitive ion channels (Patapoutian et al. 2003). These channels are characterized by their high temperature sensitivities; the $Q_{10}$ values of the TRP channels, which describe the rate of change in the current amplitude when the temperature is elevated by $10^{\circ} \mathrm{C}$, exceed 7 (Vriens et al. 2014). Furthermore, biochemical processes are temperature-sensitive in general (Elias et al. 2014). For example, $Q_{10} \approx 1-3$ for typical enzymatic reactions and ion channels, with the exception of thermo TRP channels. We also need to bear in mind that cellular systems involve coordinated functions of proteins. The $\mathrm{Ca}^{2+}$ channels, exchangers, pumps, and $\mathrm{Ca}^{2+}$-binding proteins maintain intracellular $\mathrm{Ca}^{2+}$ homeostasis and $\mathrm{Ca}^{2+}$ signaling (Berridge et al. 2003). The temperature sensitivity of the whole $\mathrm{Ca}^{2+}$ regulatory system may be a non-linear combination of the sensitivities 
of individual reactions, so it is usually difficult to predict until examined.

This review focuses on optical methods for manipulating the local temperature of cells to directly control a variety of cellular temperature-sensing systems. Optical heating is suitable for analyzing cellular temperature-sensing systems for the following reasons. First, it is well compatible with imaging-based analyses using optical microscopes. Second, it is free from the focus drift caused by the thermal expansion of materials such as plastics, glasses, and metallic components, which occurs when they are heated globally. We begin by introducing the optical microheaters and thermometers that have been used in microheating studies. Unique temperaturesensing systems in cells have been revealed and manipulated by these opto-thermal technologies, especially for muscle contractions, which is reviewed in this paper, followed by discussion on future prospects.

\section{Microscopic temperature manipulation}

Pioneering studies have used a macro-heater or macro-cooler to produce spatial temperature gradients in microscopic areas. For instance, the macro-heater and macro-cooler comprise two copper fins connected with either hot or cold reservoirs (Ishizaka 1969). A linear temperature gradient of $1.5-6.5^{\circ} \mathrm{C}$ per $100 \mu \mathrm{m}$ was created over a grasshopper spermatocyte by adjusting the gap between the pair of fins. Nicklas fabricated a "microheater" with a resistance wire heater on a glass needle to apply a localized temperature gradient to a single cell (Nicklas 1973). The wire of a thickness of about 1.5-2 $\mu \mathrm{m}$ was bent in a U-shape of a diameter of $100 \mu \mathrm{m}$ at the tip of the microheater. The temperature gradient was $10{ }^{\circ} \mathrm{C}$ and $15^{\circ} \mathrm{C}$ in $10 \mu \mathrm{m}$ and $50 \mu \mathrm{m}$ from the microheater, respectively.

A temporal temperature gradient has been produced by optical heating. Optical temperature-jump (T-jump) methods are frequently used in studies of protein thermodynamics. For instance, a water-soluble triphenylmethane dye crystal violet was heated by a 532-nm laser pulse to induce the unfolding of RNase A (Phillips et al. 1995). The rate of temperature rise was $10{ }^{\circ} \mathrm{C}$ per $70 \mathrm{ps}$. Microscopic analyses with T-jump methods have enabled evaluation of the tension response of muscle fibers to fast temperature rises (Ranatunga 2018). Compared with the relatively fast temperature rise, the uniform heating of solutions with T-jump methods results in slow recovery to the initial temperature $(\sim 10 \mathrm{~s})$ (Goldman et al. 1987).

Optical microheaters have resolved this issue by decreasing the volume of the heat source (Fig. 1). An early attempt at this was "temperature pulse microscopy" using an aluminum aggregate (dimension $\sim 10 \mu \mathrm{m}$ ) on a glass coverslip. The aggregate was heated by focusing a 1053-nm laser light to produce a concentric temperature gradient up to

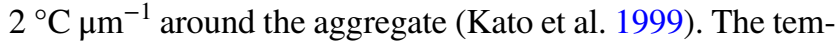
perature gradient could be removed quickly by terminating the laser light irradiation. Square-wave heat pulses (originally referred to as "temperature pulses") were created with rise and fall times of $\sim 10 \mathrm{~ms}$. If the aluminum aggregate was attached to the tip of a glass micropipette (tip $\phi \sim 1 \mu \mathrm{m}$ ) on micro manipulators, the heat source could be positioned at arbitrary locations (Zeeb et al. 2004).

Optical heating of nanomaterials is an effective strategy to minimize the volume of the heat source. Gold nanospheres illuminated by $532-\mathrm{nm}$ laser light were shown to heat human embryonic fibroblast WS1 cells locally (Kucsko et al. 2013). Owing to the low absorption of near-infrared (NIR) light ( 650-900 nm) by biological samples (Weissleder 2001), NIR-absorbable gold nanoshells (Loo et al. 2005; Gobin et al. 2007; Marino et al. 2017), gold nanonods (Huang et al. 2006; Eom et al. 2014; Yoo et al. 2014; Yong et al. 2014), and star-shaped gold nanoparticles (Zhu et al. 2021) have been developed for photothermal stimulation in deep tissues. NIR light was also used to heat carbon nanomaterials such as carbon nanotubes (Kam et al. 2005; Miyako et al. 2012b) and carbon nanohorns (Miyako et al. 2012a). Miyako et al. conjugated the NIR fluorescent dye IRDye800CW to carbon nanohorns to enhance the heat power of the nanomaterials in cells (Miyako et al. 2014).

Optical microheating without materials is convenient to target arbitrary positions, especially in vivo. Optical laser traps (optical tweezers) with 1064-nm laser light were reported to directly heat membranes of $\mathrm{CHO}$ cells with heating efficiency of $\sim 1.15^{\circ} \mathrm{C}$ per $100 \mathrm{~mW}$ (Liu et al. 1995). Water-absorbed laser light achieves heating more efficiently. Kamei et al. used 1480-nm laser light for heating acrylamide gel as an in vitro tissue model with a heating rate of $\sim 1{ }^{\circ} \mathrm{C}$ $\mathrm{mW}^{-1}$ and then applied the method in living $C$. elegans to activate heat shock promoter, followed by the induction of gene expression only in targeted cells (Kamei et al. 2009).

\section{Microscopic temperature measurement}

Thermocouples are commonly used to measure the temperature in solution, but they are too large for the scale of single cells. Therefore, in early studies, the temperature was visualized by the dewing point $\left(31^{\circ} \mathrm{C}\right)$ and freezing front $\left(0{ }^{\circ} \mathrm{C}\right)$ (Ishizaka 1969) or estimated from the birefringence of mitotic spindles (Nicklas 1973).

The development of microscopic luminescence thermometry has constituted progress in fluorescence microscopy (Fig. 1). Temperature changes alter the luminescence properties of temperature probes such as intensity, absorption and emission spectra, polarization, and lifetime (Jaque and Vetrone 2012; Brites et al. 2012; Zhou et al. 2020). 


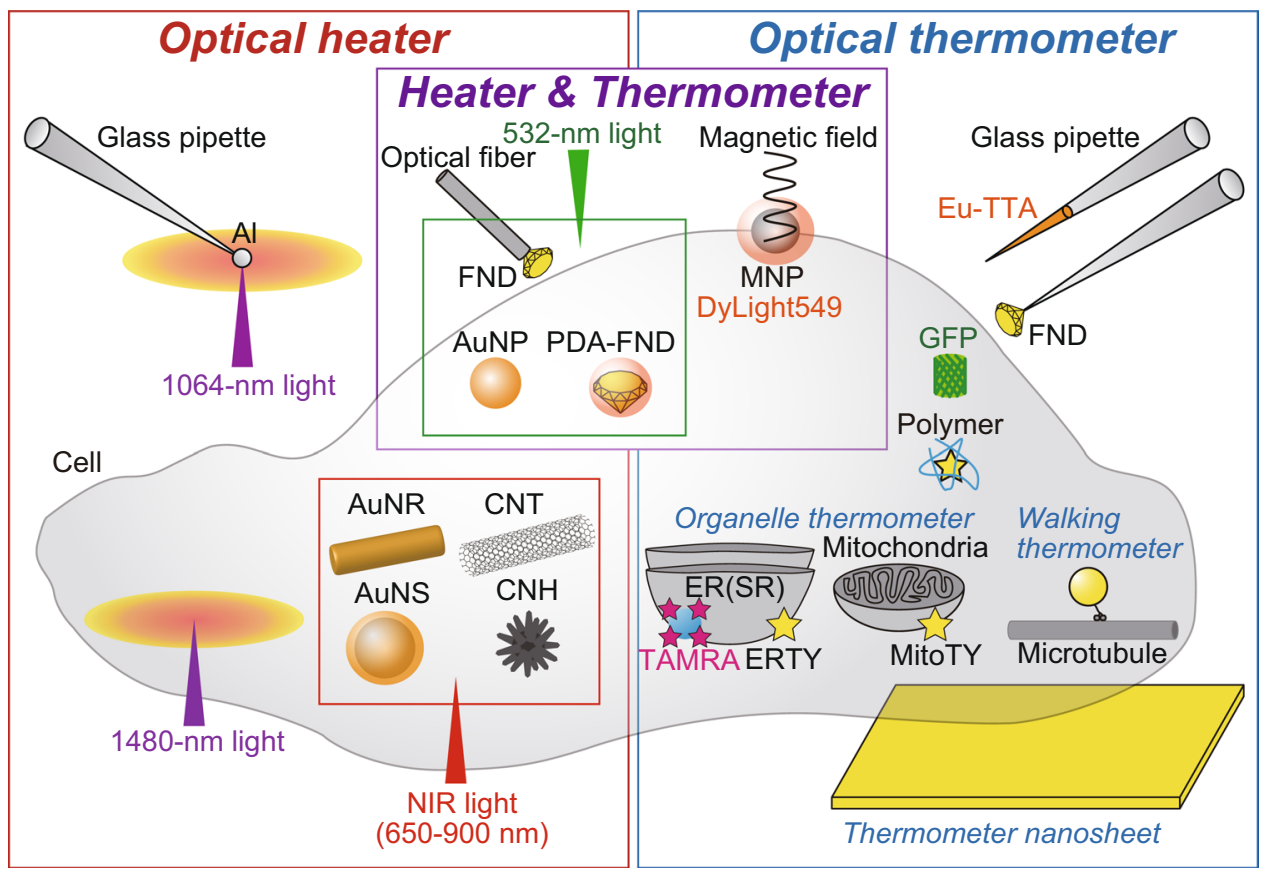

Fig. 1 Optical microheaters and thermometers for cell analyses. Left, optical heating of aluminum (Al) particles attached to the tip of a glass micropipette generates square-shaped heat pulses (Zeeb et al. 2004). Water-absorbable light can heat the cells directly without materials. Gold nanorod (AuNR), gold nanoshell (AuNS), carbon nanotube $(\mathrm{CNT})$, and carbon nanohorn $(\mathrm{CNH})$ are excited by near-infrared (NIR) light (see text for details). Right, glass pipette that either encloses luminescent thermometer europium (III) thenoyltrifluoroacetonate trihydrate (Eu-TTA) (Zeeb et al. 2004) or attaches a fluorescent nanodiamond (FND) at the tip (Romshin et al. 2021) detect local temperature in extracellular solution. Thermometer nanosheet containing Eu-TTA visualizes surface temperature of cells (Itoh et al. 2014; Oyama et al. 2020). Temperature-sensitive fluorescent polymer (Tseeb et al. 2009) and green fluorescent protein (GFP) (Kamei et al. 2009) and its sophisticated derivatives (Nakano et al. 2017; Vu et al. 2021) are used as intracellular thermometers in microheating studies. Thermometer nanoparticles are enclosed in endosomes and transported along microtubules (named "walking thermometer") (Oyama et al. 2012b). "Organelle thermometers" such as ER thermo yellow (ERTY) (Arai et al. 2014), Mito thermo yellow (MitoTY) (Arai et al. 2015b), and 5(6)-carboxytetramethylrhodamine (TAMRA)-azide (Hou et al. 2016) are targeted to specific organelles and can visualize the steep temperature gradient in cells during heating. Center, hybrid materials working as both heaters and thermometers have been developed with FNDs such as an FND attached to the tip of an optical fiber (Fedotov et al. 2015) or FNDs coated with the photothermal agent polydopamine (PDA) (Sotoma et al. 2021). Gold nanoparticles (AuNPs) are excited, and the changes of refractive index of the medium are probed for temperature measurement (Song et al. 2021). Magnetic nanoparticles (MNPs) covered with fluorescent thermometer dye DyLight594 are excited by radio-frequency magnetic field (Huang et al. 2010)
Microscopic temperature imaging in solution can be performed by relatively simple methods that detect the thermal quenching of water-soluble luminescent dyes such as rhodamine B (Ross et al. 2001), BCECF (Braun and Libchaber 2002), and tetramethylrhodamine or Alexa Fluor 555 conjugated to dextran (Oyama et al. 2015a). Luminescent nanosheets containing the temperature-sensitive dye europium (III) thenoyltrifluoroacetonate trihydrate (Eu-TTA) visualize the temperature distribution on the glass surface during optical microheating of solution (Itoh et al. 2014; Oyama et al. 2020). Romshin et al. determined the temperature gradient using a fluorescent nanodiamond (FND) attached to the tip of a glass micropipette (Romshin et al. 2021).

Luminescence properties of the temperature probes can also be affected by non-thermal environmental parameters such as $\mathrm{pH}$. This issue can be resolved by a probe that has perfect robustness. For example, temperature-sensitive dye can be covered by another material that functions as a coating to protect the dye from environmental changes. We demonstrated this strategy experimentally for the first time, where Eu-TTA dye was enclosed in a glass micropipette (Zeeb et al. 2004). We further expanded this strategy by developing robust polymer-nanoparticles embedding temperature-sensitive luminescent dyes (Oyama et al. 2012b; Takei et al. 2014; Arai et al. 2015a; Ferdinandus et al. 2016).

Intracellular luminescent thermometry has been developed to detect cellular thermogenesis (Suzuki et al. 2016; Okabe et al. 2018; Zhou et al. 2020). The same luminescent thermometers are applicable in combination with microheating methodologies. Temperature-sensitive fluorescent polymers (Uchiyama et al. 2004) injected into HeLa cells demonstrated that the temperature in the cytoplasm rose and dropped within 300 and $100 \mathrm{~ms}$, respectively, in 
response to a heat pulse, where the heat pulse was created by an aggregate of aluminum nanoparticles illuminated by a focused 1064-nm laser light (Tseeb et al. 2009). The 3D temperature distributions in acrylamide gel during heating with a 1480 -nm laser light were visualized using $E$. coli overexpressing GFP (Kamei et al. 2009). Genetically encoded fluorescent thermometers measured the temperature changes in cytoplasm (Nakano et al. 2017) and nuclei (Vu et al. 2021) during opto-thermal microheating. FNDs were also demonstrated to detect temperature gradients in cells when intracellular gold nanoparticles were illuminated by 532-nm light (Kucsko et al. 2013) or when heated by focused 1480-nm laser light (Choi et al. 2020). Other examples are small molecules targeted to the endoplasmic reticulum (ER) (Arai et al. 2014) and mitochondria (Arai et al. 2015b), or fluorescent nanosensors targeted to ER by an intracellular bottom-up approach (Hou et al. 2016). These organelle-targeted fluorescent probes visualized the temperature gradients in respective organelles during local heating.

Two technologies of temperature manipulation and thermometry need to be combined in single hybrid nanomaterials to determine the temperature of the nanomaterial as a small heat source (Fig. 1). Superparamagnetic nanoparticles were coated with the temperature-sensitive dye DyLight549 to measure the temperature of the nanoparticle surface (Huang et al. 2010). Fluorescent diamonds have been used as hybrid materials in several ways. For instance, diamond microcrystal attached to the tip of an optical fiber was heated by a 532-nm laser (Fedotov et al. 2015). Nanohybrids of gold nanorod-FND (Tsai et al. 2015) were used to determine the rupture temperature of cell membranes (Tsai et al. 2017). Sotoma et al. coated FND with polydopamine demonstrating photothermal conversion. They successfully measured the intracellular thermal conductivity for the first time as about one-sixth of that of water, where significant variation of the value was also recognized (Sotoma et al. 2021). To map the possible inhomogeneity of the heat transfer in a cell, $\mathrm{Au}$ nanoparticles were pumped with a 532-nm laser for heating locally, while the localized temperature changes were probed using white light by detecting the temperature-dependent changes of the refractive index of the surrounding medium (Song et al. 2021).

\section{Cellular responses to spatial temperature gradient}

The spatial gradient of the temperature is formed in tissues in the range of $\sim 0.01-1{ }^{\circ} \mathrm{C} \mathrm{mm}^{-1}$. For instance, the temperature gradients across skin and eye are $0.2-0.5^{\circ} \mathrm{C} \mathrm{mm}^{-1}$ (Bazett and McGlone 1927) and $0.1-1.3^{\circ} \mathrm{C} \mathrm{mm}^{-1}$ (Schwartz and Feller 1962), respectively. In rabbit oviduct, the temperature difference between the sperm storage site and fertilization site (the distance between two sites is $\sim 100 \mathrm{~mm}$ ) is increased from 0.8 to $1.6^{\circ} \mathrm{C}$ after ovulation (Bahat et al. 2005). From these values, the temperature difference across a single cell $(\sim 10 \mu \mathrm{m})$ is calculated as $\sim 0.0001-0.01^{\circ} \mathrm{C}$ when a one-dimensional homogeneous temperature gradient is assumed. These tiny temperature gradients are known to affect cellular behaviors. Human sperm cells show thermotaxis; they respond to the temperature gradient of $<0.014{ }^{\circ} \mathrm{C} \mathrm{mm}^{-1}$ and migrate toward the warmer side (Bahat et al. 2003, 2012). Surprisingly, the temperature difference in the cell body $(46 \mu \mathrm{m})$ is $<0.0006^{\circ} \mathrm{C}$.

A temperature gradient affects the process of cell division. A temperature gradient $\left(6^{\circ} \mathrm{C}\right.$ per $\left.100 \mu \mathrm{m}\right)$ along the spindle of anaphase spermatocytes accelerates the development of the aster at the warmer side, moves the spindle toward the cooler side, and induces asymmetric division (Ishizaka 1969). Nicklas applied a steeper gradient than that of the previous study $\left(15^{\circ} \mathrm{C}\right.$ per $\left.50 \mu \mathrm{m}\right)$ and observed accelerated chromosome separation at warmer side (Nicklas 1979). The plasma membrane at the hotter side of a mitotic HeLa cell is extended toward the heat source, termed a polar bleb, due to the asymmetric movement of actomyosin cortex by imbalanced actomyosin contractile forces (Oyama et al. 2015a) (Fig. 2a). The minimum temperature difference within the cell $(\sim 20 \mu \mathrm{m})$ to form the polar bleb was found to be $1.3{ }^{\circ} \mathrm{C}$, or over $65^{\circ} \mathrm{C} \mathrm{mm}^{-1}$. Such a large gradient has not been observed in tissues, but it may be formed in thermal therapies using nano-/micromaterial heaters (Rajan and Sahu 2020; Liao et al. 2021).

Cellular response to the temperature gradient is also the subject of studies examining the mechanism in the optical guidance of neurite outgrowth. Ebbesen and Bruus calculated the temperature gradient during the optical guidance using an infrared (IR) laser light and proposed that the heat activation of TRP channels mediates the neuronal guidance (Ebbesen and Bruus 2012). Their conclusion matched the experimental findings; TPRV1 antagonist suppressed repulsive response of growth cone to the focused 785-nm laser light (Black et al. 2016). We observed the attraction of neurite outgrowth of rat hippocampal neurons toward the heat source that was formed by 1455-nm IR laser light (Oyama et al. 2015b). While the neurite outgrowth was independent of the TRP channels' activity, substantial but non-essential contribution of $\mathrm{Ca}^{2+}$ influx was demonstrated. We proposed the mechanism based on heat-accelerated polymerization of actin filaments and microtubules and their sliding by molecular motors.

\section{Cellular responses to temporal temperature gradient}

The previous section summarized cellular responses to the spatial temperature gradient that is formed in a steady state. Here, we show that the sudden changes in temperature can 
(a)

Responses to spatial temperature gradient

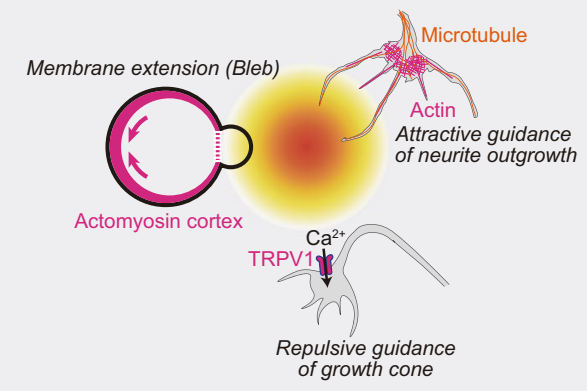

(c)

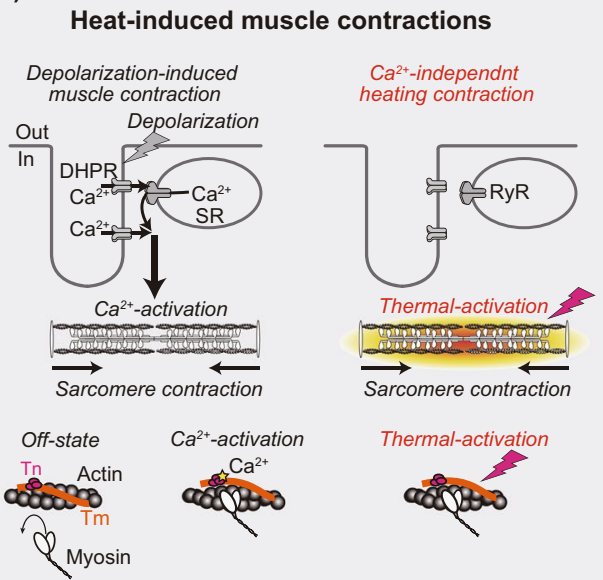

(b)

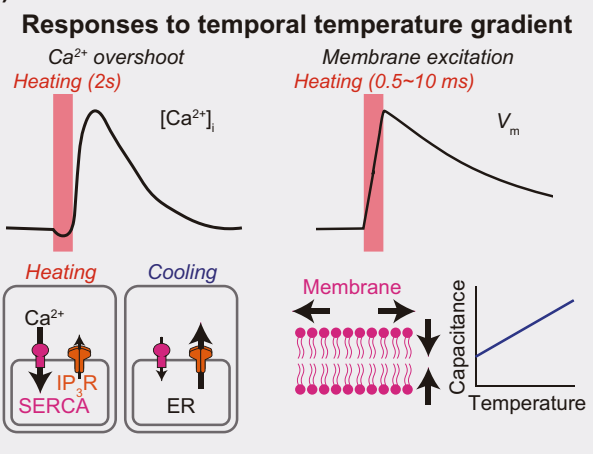

(d)

Thermal hyperactivation beyond denaturation
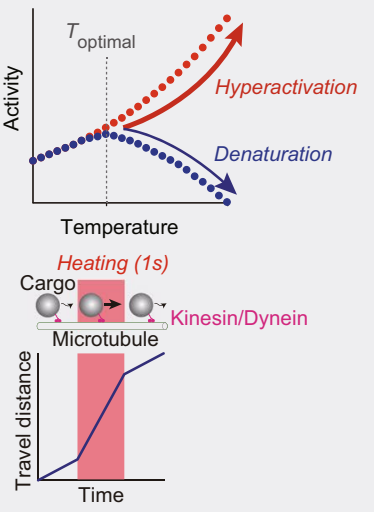

Fig. 2 Cellular responses to spatial and temporal temperature gradients. a Responses to spatial temperature gradient. Left, spherical mitotic cells extend the plasma membrane (bleb) toward the heat source with asymmetric movement of actomyosin cortex (Oyama et al. 2015a). Right, neurites elongated toward the heat source with enhanced polymerization/sliding of microtubules and actin filaments (Oyama et al. 2015b). Bottom, repulsive guidance of growth cone is triggered by heat-activated $\mathrm{Ca}^{2+}$ influx through transient receptor potential channels (TRPV1) (Black et al. 2016). b Responses to temporal temperature gradient. Left, heat pulse elevates the intracellular concentration of $\mathrm{Ca}^{2+}\left(\left[\mathrm{Ca}^{2+}\right]_{\mathrm{i}}\right)$ due to $\mathrm{Ca}^{2+}$ release from intracellular $\mathrm{Ca}^{2+}$ store endoplasmic reticulum (ER) (Tseeb et al. 2009; Itoh et al. 2014). During heating, $\mathrm{Ca}^{2+}$ uptake by sarco-/endoplasmic reticulum $\mathrm{Ca}^{2+}$ ATPase (SERCA) is activated (larger arrow). At the end of heating, $\mathrm{Ca}^{2+}$ release through inositol trisphosphate receptors

also cause various cellular responses that range from $\mathrm{Ca}^{2+}$ signaling to membrane excitation.

Rapid cooling induces intracellular $\left[\mathrm{Ca}^{2+}\right]\left(\left[\mathrm{Ca}^{2+}\right]_{\mathrm{i}}\right)$ increases in various types of cell. For instance, rapid cooling from $36.5{ }^{\circ} \mathrm{C}$ to a temperature below $18{ }^{\circ} \mathrm{C}$ induces guinea pig cardiac muscle contractures, named rapid cooling contractures (RCC) (Kurihara and Sakai 1985). The maximum tension during RCC depends on the rate of cooling (Sakai and Kurihara 1974). The rapid cooling induces $\mathrm{Ca}^{2+}$ release from intracellular $\mathrm{Ca}^{2+}$ store sarcoplasmic reticulum (SR) mainly through ryanodine receptors (RyRs) (Protasi et al. 2004) and probably also through inositol trisphosphate
$\left(\mathrm{IP}_{3} \mathrm{R}\right)$ is enhanced (larger arrow). Right, rapid heating elevates membrane potential $\left(V_{\mathrm{m}}\right)$ with capacitance increase (Shapiro et al. 2012; Liu et al. 2014) due to geometric changes of bilayer (arrows) (Plaksin et al. 2018). c Mechanisms of muscle contractions triggered by depolarization of sarcolemma (left) or $\mathrm{Ca}^{2+}$-independent thermal activation of contractile systems (right) (see text for details). d Thermal hyperactivation of molecular motors. Long exposure of temperature higher than optimal temperature $\left(T_{\text {optimal }}\right)$ decreases the enzymatic activity due to thermal denaturation (blue plots). Short heating enables an increase in enzymatic activity, which is higher than the maximal activity at $T_{\text {optimal }}$ (red plots). This hyperactivation of molecular motors interacting with the cytoskeleton has been observed in vitro (Kato et al. 1999; Kawaguchi and Ishiwata 2001) and in cells (Oyama et al. 2012b).

receptors $\left(\mathrm{IP}_{3} \mathrm{Rs}\right)$ (Talon et al. 2000), both of which are SR $\mathrm{Ca}^{2+}$ release channels. Cooling elevates the open probability of RyRs (Sitsapesan et al. 1991). Additionally, cooling decreases the activity of sarco-/endoplasmic reticulum $\mathrm{Ca}^{2+}$ ATPase (SERCA) (Dode et al. 2001; Landeira-Fernandez et al. 2004), which is suggested to increase the net $\mathrm{Ca}^{2+}$ leak from SR. Rapid cooling is also known to induce $\left[\mathrm{Ca}^{2+}\right]_{i}$ increases in Paramecium (Inoue and Nakaoka 1990) and in plant cells (Plieth et al. 1999; Nagel-Volkmann et al. 2009).

Interestingly, similar $\left[\mathrm{Ca}^{2+}\right]_{\mathrm{i}}$ increases are also induced by a heat pulse for several seconds. When a heat pulse for $2 \mathrm{~s}$ was applied to HeLa cells, there was a $\left[\mathrm{Ca}^{2+}\right]_{\mathrm{i}}$ decrease 
during heating, followed by its overshoot after the end of the heating (Tseeb et al. 2009) (Fig. 2b, upper left). The minimum temperature rise that was required to induce the $\mathrm{Ca}^{2+}$ overshoot was $1.5^{\circ} \mathrm{C}$ at $22^{\circ} \mathrm{C}$, which was reduced to $0.2^{\circ} \mathrm{C}$ at $37^{\circ} \mathrm{C}$. Human fibroblast WI-38 cells responded in a similar manner (Itoh et al. 2014). In both cells, the increase in $\left[\mathrm{Ca}^{2+}\right]_{\mathrm{i}}$ was suppressed by the inhibitors of $\mathrm{IP}_{3} \mathrm{R}$, strongly suggesting that $\mathrm{IP}_{3} \mathrm{R}$ is the major $\mathrm{Ca}^{2+}$ release channel in the heat pulse-induced $\left[\mathrm{Ca}^{2+}\right]_{i}$ increase. A plausible mechanism explaining this is as follows (Fig. 2b, lower left): (i) Heating elevates the net $\mathrm{Ca}^{2+}$ flow from the cytoplasm toward ER due to increased SERCA activity and probably decreased open probability of $\mathrm{IP}_{3} \mathrm{R}$ (similar temperature sensitivity of the open probability as proposed in RCC). The electrochemical potential of $\mathrm{Ca}^{2+}$ across the ER membrane is enhanced. (ii) At the end of heating, the net $\mathrm{Ca}^{2+}$ flow is quickly reversed as the activities of SERCA and $\mathrm{IP}_{3} \mathrm{R}$ immediately return to

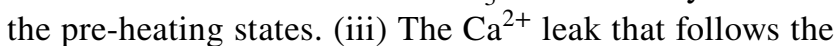
enhanced $\mathrm{Ca}^{2+}$ gradient serves as the initial $\mathrm{Ca}^{2+}$ for a large $\mathrm{Ca}^{2+}$ leak known as the $\mathrm{Ca}^{2+}$-induced $\mathrm{Ca}^{2+}$ release of $\mathrm{IP}_{3} \mathrm{R}$. In summary, the $\mathrm{Ca}^{2+}$ response observed here is a result of the asymmetry between the temperature sensitivities of $\mathrm{Ca}^{2+}$ pumps and $\mathrm{Ca}^{2+}$ release channels and their thermal perturbation.

Rapid heating also induces excitation of the cell membrane. Wells et al. previously observed IR stimulation of neuronal cells (Wells et al. 2005). They examined photochemical, photomechanical, and photothermal effects on sciatic nerve and concluded that the photothermal effect causes activation of the plasma membrane (Wells et al. 2007). Shapiro et al. showed that the electrical capacitance of the membrane without ion channels is increased by rapid heating (Shapiro et al. 2012) (Fig. 2b, right). They proposed a theoretical explanation for this based on the GouyChapman-Stern theory (Genet et al. 2000) that rapid heating induces asymmetric charge displacements at the intracellular and extracellular sides of the plasma membrane. The rate of temperature rise was the key parameter for exciting the cell membrane of C. elegans (Liu et al. 2014), which was consistent with the model (Shapiro et al. 2012). Plaksin et al. pointed out an error in the theoretical modeling and proposed an alternative theory considering dimensional changes in the membrane (Plaksin et al. 2017, 2018) (Fig. 2b, right).

\section{Muscle contractions induced by heat pulses}

IR cardiac stimulation is effective for the optical pacing of hearts. Smith et al. succeeded in inducing $\left[\mathrm{Ca}^{2+}\right]_{\mathrm{i}}$ transients in rat neonatal cardiomyocytes using a 780-nm femtosecond pulse laser light (Smith et al. 2008). Their efforts were based on their own findings that pulse laser light induced $\left[\mathrm{Ca}^{2+}\right]_{\mathrm{i}}$ increase in HeLa (Smith et al. 2001; Iwanaga et al. 2006) and PC12 cell lines (Smith et al. 2006). Pulsed 1875-nm laser light was also reported to achieve optical pacing of quail embryonic heart (Jenkins et al. 2010). The membrane excitation induced by opto-thermal stimulations (Shapiro et al. 2012) could trigger $\mathrm{Ca}^{2+}$ influx through sarcolemma voltage-sensitive $\mathrm{Ca}^{2+}$ channels and $\mathrm{Ca}^{2+}$ release from intracellular $\mathrm{Ca}^{2+}$ store $\mathrm{SR}$, as well as physiological cardiac contractions (Bers 2002). Other $\mathrm{Ca}^{2+}$ sources are additionally suggested. Dittami et al. investigated the mechanism of $\left[\mathrm{Ca}^{2+}\right]_{\mathrm{i}}$ transients in rat neonatal cardiomyocytes evoked by pulsed IR light $(1862 \mathrm{~nm})$ and concluded that the major intracellular $\mathrm{Ca}^{2+}$ sources were mitochondria (Dittami et al. 2011). Similarly, inhibitors of mitochondrial $\mathrm{Ca}^{2+}$ cycling suppressed the $\left[\mathrm{Ca}^{2+}\right]_{\mathrm{i}}$ transients evoked by IR laser light in rat ganglion neurons (Lumbreras et al. 2014). Thus, mitochondria might also be the $\mathrm{Ca}^{2+}$ source of the $\left[\mathrm{Ca}^{2+}\right]_{\mathrm{i}}$ transients induced by opto-thermal stimulations in these cells.

Train of sub-second heat pulses over $\sim 40{ }^{\circ} \mathrm{C}$ can induce repeated $\mathrm{Ca}^{2+}$-independent muscle contractions. Cardiomyocytes isolated from adult rats were also found to repeat the cycle of contraction and relaxation as a response to heat pulses (0.2 s) applied at $2.5 \mathrm{~Hz}$ (Oyama et al. 2012a). The contraction induced by heating from 36 to $41^{\circ} \mathrm{C}$ was suppressed by a myosin II inhibitor, blebbistatin. The $\left[\mathrm{Ca}^{2+}\right]_{\mathrm{i}}$ was stable during the contraction. These results strongly suggest that the heating triggers the interaction of actin and myosin in a $\mathrm{Ca}^{2+}$-independent manner (Fig. 2c). Shintani et al. further investigated the effect of heating on sarcomere dynamics with high-precision measurement of sarcomere lengths in rat neonatal cardiomyocytes and found that heating to $\sim 38{ }^{\circ} \mathrm{C}$ induced $\mathrm{Ca}^{2+}$-independent high-frequency $(5-10 \mathrm{~Hz})$ sarcomeric oscillations termed hyperthermal sarcomeric oscillations (HSOs) (Shintani et al. 2015).

What is the mechanism of these heat-induced $\mathrm{Ca}^{2+}$-independent muscle contractions? Physiological cardiac contractions are regulated by $\left[\mathrm{Ca}^{2+}\right]_{\mathrm{i}}$ as follows (Bers 2002) (Fig. 2c). (i) Depolarization of excited sarcolemma triggers $\mathrm{Ca}^{2+}$ influx through voltage-sensitive $\mathrm{Ca}^{2+}$ channel [dihydropyridine receptor (DHPR)] at the sarcolemma. (ii) The $\mathrm{Ca}^{2+}$ influx from extracellular space triggers intracellular $\mathrm{Ca}^{2+}$ release from SR. (iii) $\mathrm{The}^{\mathrm{Ca}^{2+}}$ influx and release increase $\left[\mathrm{Ca}^{2+}\right]_{\mathrm{i}}$, which promotes $\mathrm{Ca}^{2+}$ binding to troponin $\mathrm{C}(\mathrm{TnC})$ on thin filaments. (iv) $\mathrm{The} \mathrm{Ca}^{2+}$ binding to $\mathrm{TnC}$ shifts the state of thin filaments to "on," which allows the interaction of actomyosin. (v) Sarcomere shortening is initiated. (vi) $\mathrm{As}\left[\mathrm{Ca}^{2+}\right]_{\mathrm{i}}$ decreases mainly due to $\mathrm{Ca}^{2+}$ uptake into SR by SERCA and $\mathrm{Ca}^{2+}$ efflux by sarcolemmal $\mathrm{Na}^{+}$/ $\mathrm{Ca}^{2+}$ exchanger, $\mathrm{Ca}^{2+}$ dissociates from $\mathrm{TnC}$ and the state of thin filaments shifts to "off," which blocks actomyosin interaction.

Heat-induced contraction without $\left[\mathrm{Ca}^{2+}\right]_{\mathrm{i}}$ increase could be explained from the perspective of $\mathrm{Ca}^{2+}$-independent thermal activation of thin filaments (Ishii et al. 2020). In an 
in vitro motility assay, reconstituted cardiac thin filaments slid on myosin in $\mathrm{Ca}^{2+}$-free solution when the temperature was increased over $\sim 43{ }^{\circ} \mathrm{C}$ (Brunet et al. 2012). Optical rapid heating initiated the $\mathrm{Ca}^{2+}$-independent sliding within $30 \mathrm{~ms}$ (Ishii et al. 2019). These results show that actomyosin interaction is enhanced by heating without $\mathrm{Ca}^{2+}$. Interestingly, the sliding speed in $\mathrm{Ca}^{2+}$-free solution at $37^{\circ} \mathrm{C}$ was about $30 \%$ of that in a $\mathrm{Ca}^{2+}$-activated state, suggesting that cardiac muscles are partially activated in the relaxed condition (diastole) at physiological temperature for rapid and efficient contraction in systole.

Similar $\mathrm{Ca}^{2+}$-independent contraction was also demonstrated using NIR laser light and the photothermal property of gold nanoshells that were internalized in myotubes differentiated from the skeletal muscle model $\mathrm{C} 2 \mathrm{C} 12$ cell line (Marino et al. 2017). At least three processes could be suggested to explain the heat-activated muscle thin filaments. First, the regulatory proteins may have partially dissociated during heating. The complex of tropomyosin (Tm)-Tn has been shown to dissociate from actin filaments at temperatures above $\sim 41{ }^{\circ} \mathrm{C}$ (Ishiwata 1978). Heating unfolds the coiled-coil domains of $\mathrm{Tm}$ and decreases the affinity with actin (Kremneva et al. 2003). Initiation of these processes on thin filaments could contribute to the $\mathrm{Ca}^{2+}$-independent activation of thin filaments during the heat pulses. Second, heating increases the affinity of $\mathrm{TnC}$ to $\mathrm{Ca}^{2+}$ (Gillis et al. 2000; Veltri et al. 2017), allowing for actomyosin interaction during heating at relatively low $\left[\mathrm{Ca}^{2+}\right]_{\mathrm{i}}$. Lastly, heating also elevates the affinity of actin and myosin (Highsmith 1977, 1978) and increases the number of force-generating crossbridges (Zhao and Kawai 1994); that is, crossbridge force generation is endothermic (Ranatunga 2018). These properties of actomyosin could result in the cooperative formation of crossbridges as well as the strong binding of myosin, which ensures the proximity of the myosin binding sites on the thin filament in the absence of $\mathrm{Ca}^{2+}$ (Lehman 2017; Geeves et al. 2019).

\section{Thermal hyperactivation of enzymes without denaturation}

Enzymatic reactions of proteins are elevated by a temperature rise, as described by the Arrhenius equation, but proteins are inactivated due to thermal denaturation when overheated above the inherent optimal temperature (Daniel and Danson 2013) (Fig. 2d). However, protein denaturation is a time-dependent process. Enzymes exposed to temperatures above the optimal temperature could be hyperactivated at the beginning of the heating according to the Arrhenius equation, and they are then denatured if the heating continues thereafter. This scenario has been directly demonstrated in a microscopic experiment in vitro, where actomyosin motors were reversibly hyperactivated above physiological temperature $\left(>60{ }^{\circ} \mathrm{C}\right)$ for a short period $(62.5 \mathrm{~ms})$ of heating (Kato et al. 1999). The gliding velocity of microtubules over kinesin molecules in vitro was increased at the temperature up to $50{ }^{\circ} \mathrm{C}$ for $2 \mathrm{~s}$ by following the Arrhenius equation, whereas kinesins were inactivated after heating at $35^{\circ} \mathrm{C}$ for 1 min (Kawaguchi and Ishiwata 2001). Heating to $100{ }^{\circ} \mathrm{C}$ for tens of nanoseconds ( $40 \mathrm{~ns})$ caused no apparent thermal denaturation of catalase, and the rate of inactivation at up to $\sim 174{ }^{\circ} \mathrm{C}$ is consistent with the Arrhenius equation (Steel et al. 2006). In HeLa cells, the velocity of endosomes transported on microtubules by the molecular motor kinesin or dynein was increased during heating up to $47^{\circ} \mathrm{C}$ for $1 \mathrm{~s}$ (Oyama et al. 2012b). Thus, a short period of heating $(\sim 2 \mathrm{~s})$ hyperactivates enzymes to exceed their steady state maximal speed at the optimal temperature.

Thermal hyperactivation of enzymatic reactions may enable us to control cellular functions in an analog way by adjusting the amplitude of opto-thermal stimulation. This is in contrast with other optical manipulations such as optogenetics, which are usually based on on-off digital regulation. The method may also be applied to achieve enhanced performance of cells beyond the physiological level.

\section{Advantages and limitations of opto-thermal cellular manipulation}

The combination of optical heating and cells engineered with the heat shock promoter-mediated gene expression systems is used for spatial and remote regulation of cellular activities (Kamei et al. 2009; Miyako et al. 2012a; Miller et al. 2018). Temperature-sensitive mutant of myosin II was also employed for local inactivation of the mutant in $C$. elegans embryos, and the division failures were induced in targeted cells (Hirsch et al. 2018). Moreover, opto-thermal cellular manipulation can target endogenous temperaturesensing systems (Table 1). It is not necessary to express light-sensitive proteins or introduce light-sensitive materials. Therefore, opto-thermal methods are suitable especially in in vivo applications and in non-model species and are even applicable for thermal therapy.

Opto-thermal manipulation is effective to modulate multiple types of protein or process simultaneously, which is challenging in methods based on light-sensitive proteins and materials. On the other hand, for the same reason, selective targeting is not achieved when micrometer-scale heaters are used. To add selectivity, attaching nanoheaters to the targeted proteins is an effective strategy (Stanley et al. 2012; Iwaki et al. 2015).

Optical heating with NIR light is suitable for deep tissue applications. For instance, Miyako et al. injected carbon nanohorns with IR $800 \mathrm{CW}$ under the thigh of frog expressing thermo TRP channels in nerves endogenously 
Table 1 Cellular responses to opto-thermal stimulations

\begin{tabular}{|c|c|c|c|c|c|c|}
\hline Cellular response & Target & $\begin{array}{l}\text { Optical heater } \\
\text { (wavelength) }\end{array}$ & $\begin{array}{l}\text { Types of tem- } \\
\text { perature gradient } \\
\text { (heating period) }\end{array}$ & Thermometer & $\begin{array}{l}\text { Cellular ther- } \\
\text { mosensor }\end{array}$ & Reference \\
\hline $\begin{array}{l}\text { Membrane exten- } \\
\text { sion }\end{array}$ & $\mathrm{HeLa}$ & $\begin{array}{l}\text { CW laser } \\
\quad(1455 \mathrm{~nm})\end{array}$ & Spatial (20 s) & $\begin{array}{l}\text { Fluorescent } \\
\text { dextran }\end{array}$ & Actomyosin cortex & Oyama et al. $2015 a$ \\
\hline Neurite outgrowth & $\begin{array}{l}\text { Rat hippocampal } \\
\text { neuron }\end{array}$ & $\begin{array}{l}\text { CW laser } \\
\quad(1455 \mathrm{~nm})\end{array}$ & Spatial (60 s) & $\begin{array}{c}\text { Thermometer } \\
\text { nanosheet }\end{array}$ & $\begin{array}{l}\text { Cytoskeleton and } \\
\text { molecular motors }\end{array}$ & Oyama et al. $2015 b$ \\
\hline $\begin{array}{l}\text { Growth cone } \\
\text { repulsive } \\
\text { response }\end{array}$ & Rat cortical neuron & $\begin{array}{l}\text { CW laser (750- } \\
1000 \mathrm{~nm})\end{array}$ & Spatial $(>\min )$ & IR camera & TRPV1 & Black et al. 2016 \\
\hline$\left[\mathrm{Ca}^{2+}\right]_{\mathrm{i}}$ increase & $\mathrm{HeLa}$ & $\begin{array}{l}\text { 80-fs pulse laser } \\
\quad(780 \mathrm{~nm})\end{array}$ & $\begin{array}{l}\text { Temporal } \\
\quad(125-500 \mathrm{~ms})\end{array}$ & - & Internal $\mathrm{Ca}^{2+}$ store & Smith et al. $2001^{*}$ \\
\hline$\left[\mathrm{Ca}^{2+}\right]_{\mathrm{i}}$ increase & $\mathrm{HeLa}$ & $\begin{array}{l}\text { 80-fs pulse laser } \\
\quad(780 \mathrm{~nm})\end{array}$ & Temporal (13 ms) & - & ER & $\begin{array}{l}\text { Iwanaga et al. } \\
2006^{* *}\end{array}$ \\
\hline$\left[\mathrm{Ca}^{2+}\right]_{\mathrm{i}}$ increase & $\mathrm{PC} 12$ & $\begin{array}{l}\text { 80-fs pulse laser } \\
\quad(775 \mathrm{~nm})\end{array}$ & Temporal (13 ms) & - & - & Smith et al. $2006 *$ \\
\hline$\left[\mathrm{Ca}^{2+}\right]_{\mathrm{i}}$ increase & $\begin{array}{l}\text { Rat ganglion } \\
\text { neuron }\end{array}$ & $\begin{array}{l}\text { 4-ms pulse laser } \\
\quad(1863 \mathrm{~nm})\end{array}$ & Temporal (4 ms) & - & Mitochondria & $\begin{array}{l}\text { Lumbreras et al. } \\
2014 * *\end{array}$ \\
\hline$\left[\mathrm{Ca}^{2+}\right]_{\mathrm{i}}$ increase & HeLa & $\mathrm{Al}(1064 \mathrm{~nm})$ & Temporal (2s) & $\begin{array}{l}\text { Eu-TTA in a glass } \\
\text { pipette }\end{array}$ & $\begin{array}{l}\text { ER (SERCA and } \\
\left.I_{3} R\right)\end{array}$ & Tseeb et al. 2009 \\
\hline$\left[\mathrm{Ca}^{2+}\right]_{\mathrm{i}}$ increase & WI-38 & $\begin{array}{l}\text { CW laser } \\
(1455 \mathrm{~nm})\end{array}$ & Temporal (2 s) & $\begin{array}{c}\text { Thermometer } \\
\text { nanosheet }\end{array}$ & $\begin{array}{l}\text { ER (SERCA and } \\
\left.\mathrm{IP}_{3} \mathrm{R}\right)\end{array}$ & Itoh et al. 2014 \\
\hline$\left[\mathrm{Ca}^{2+}\right]_{\mathrm{i}}$ increase & MCF-7, HeLa & $\begin{array}{l}\text { Star-shaped AuNP } \\
\quad(830 \mathrm{~nm})\end{array}$ & Temporal (39 ms) & - & Lysosome & Zhu et al. $2021^{* *}$ \\
\hline Nerve excitation & $\begin{array}{l}\text { Sciatic nerve (frog, } \\
\text { rat) }\end{array}$ & $\begin{array}{l}\text { Pulse laser } \\
\quad(0.75-2.12 \mu \mathrm{m})\end{array}$ & $\begin{array}{l}\text { Temporal } \\
\qquad(5-5000 \mu \mathrm{s})\end{array}$ & IR camera & Plasma membrane & Wells et al. 2007 \\
\hline $\begin{array}{l}\text { Membrane excita- } \\
\text { tion }\end{array}$ & $\begin{array}{c}\text { Frog oocyte, } \\
\text { HEK293T }\end{array}$ & $\begin{array}{l}\text { Pulse laser (1869- } \\
1889 \text { nm) }\end{array}$ & $\begin{array}{l}\text { Temporal } \\
\quad(0.1-10 \mathrm{~ms})\end{array}$ & $\begin{array}{l}\text { Impedance of a } \\
\text { glass pipette }\end{array}$ & Plasma membrane & Shapiro et al. 2012 \\
\hline $\begin{array}{l}\text { Membrane excita- } \\
\text { tion }\end{array}$ & C. elegans & $\begin{array}{l}\text { Pulse laser } \\
\quad(1862 \mathrm{~nm})\end{array}$ & $\begin{array}{l}\text { Temporal } \\
\qquad(300-1500 \mu \mathrm{s})\end{array}$ & $\begin{array}{l}\text { Impedance of a } \\
\text { glass pipette }\end{array}$ & Plasma membrane & Liu et al. 2014 \\
\hline $\begin{array}{l}\text { Cardiac }\left[\mathrm{Ca}^{2+}\right]_{\mathrm{i}} \\
\text { increase and } \\
\text { contraction }\end{array}$ & $\begin{array}{l}\text { Rat neonatal car- } \\
\text { diomyocytes }\end{array}$ & $\begin{array}{l}\text { 80-fs pulse laser } \\
\quad(780 \mathrm{~nm})\end{array}$ & Temporal ( $8 \mathrm{~ms})$ & - & - & Smith et al. 2008* \\
\hline $\begin{array}{l}\text { Cardiac contrac- } \\
\text { tion }\end{array}$ & $\begin{array}{l}\text { Quail embryonic } \\
\text { heart }\end{array}$ & $\begin{array}{l}\text { Pulse laser } \\
\quad(1875 \mathrm{~nm})\end{array}$ & $\begin{array}{l}\text { Temporal } \\
\quad(1-2 \mathrm{~ms})\end{array}$ & - & - & $\begin{array}{l}\text { Jenkins et al. } \\
2010^{* *}\end{array}$ \\
\hline $\begin{array}{l}\text { Cardiac }\left[\mathrm{Ca}^{2+}\right]_{\mathrm{i}} \\
\text { increase }\end{array}$ & $\begin{array}{c}\text { Rat neonatal car- } \\
\text { diomyocytes }\end{array}$ & $\begin{array}{l}\text { Pulse laser } \\
\quad(1862 \mathrm{~nm})\end{array}$ & $\begin{array}{l}\text { Temporal } \\
\quad(3-4 \mathrm{~ms})\end{array}$ & - & Mitochondria & $\begin{array}{l}\text { Dittami et al. } \\
2011^{* *}\end{array}$ \\
\hline $\begin{array}{l}\mathrm{Ca}^{2+} \text {-independent } \\
\text { muscle contrac- } \\
\text { tion }\end{array}$ & $\begin{array}{l}\text { Rat adult cardio- } \\
\text { myocytes }\end{array}$ & $\begin{array}{l}\text { CW laser } \\
\quad(1455 \mathrm{~nm})\end{array}$ & $\begin{array}{l}\text { Temporal } \\
\quad(0.2-0.5 \mathrm{~s})\end{array}$ & $\begin{array}{l}\text { Eu-TTA in a glass } \\
\text { pipette }\end{array}$ & Sarcomere ${ }^{* * *}$ & Oyama et al. 2012a \\
\hline $\begin{array}{l}\mathrm{Ca}^{2+} \text {-independent } \\
\text { muscle contrac- } \\
\text { tion }\end{array}$ & $\begin{array}{l}\text { Rat neonatal car- } \\
\text { diomyocytes }\end{array}$ & $\begin{array}{l}\text { CW laser } \\
\quad(1455 \mathrm{~nm})\end{array}$ & Temporal (10 s) & $\begin{array}{c}\text { Thermometer } \\
\text { nanosheet }\end{array}$ & Sarcomere ${ }^{* * *}$ & Shintani et al. 2015 \\
\hline $\begin{array}{l}\mathrm{Ca}^{2+} \text {-independent } \\
\text { muscle contrac- } \\
\text { tion }\end{array}$ & $\mathrm{C} 2 \mathrm{C} 12$ myotube & AuNS (808 nm) & Temporal $(0.5 \mathrm{~s})$ & ER thermo yellow & Sarcomere ${ }^{* * *}$ & Marino et al. 2017 \\
\hline $\begin{array}{l}\text { Transporter speed- } \\
\text { up }\end{array}$ & HeLa & $\begin{array}{l}\text { CW laser } \\
\quad(1455 \mathrm{~nm})\end{array}$ & Temporal (1 s) & $\begin{array}{l}\text { Walking nanother- } \\
\text { mometer }\end{array}$ & $\begin{array}{l}\text { Endosome/lyso- } \\
\text { some-transport- } \\
\text { ing motors }\end{array}$ & Oyama et al. $2012 b$ \\
\hline
\end{tabular}

This table summarizes responses of intact cells to temperature gradients introduced in this review. Responses of cells that were engineered to overexpress temperature-sensitive proteins are not contained

*These studies did not measure changes in temperature during optical stimulation, and the contribution of the temperature was unclear

** These studies did not measure changes in temperature during optical stimulation, but the contribution of the temperature was discussed

*** The mechanism is considered to be the thermal activation of thin filament due to partial dissociation of Tm-Tn complex from actin filaments. Heating-enhanced $\mathrm{Ca}^{2+}$ binding to troponin $\mathrm{C}$ and/or myosin binding to actin filaments might be related (see text for the details)

Abbreviations: $\left[\mathrm{Ca}^{2+}\right]_{i}$ intracellular $\left[\mathrm{Ca}^{2+}\right], C W$ continuous wave, $E R$ endoplasmic reticulum, Eu-TTA europium (III) thenoyltrifluoroacetonate trihydrate, $I P_{3} R s$ inositol trisphosphate receptors, SERCA sarco-/endoplasmic reticulum $\mathrm{Ca}^{2+}$-ATPase, $T R P$ transient receptor potential 
and successfully induced twitching of the paw via irradiation of 800-nm laser light from the outside of the frog body (Miyako et al. 2014). For deeper heating, radio-frequency magnetic field heating of nanoparticles has been adapted. Huang et al. used 6-nm manganese ferrite nanoparticles to activate temperature-sensing neurons in $C$. elegans for remote manipulation of the worm (Huang et al. 2010). Magnetothermal heating has also been demonstrated to excite neurons expressing TRPV1 in mouse brain (Chen et al. 2015).

\section{Perspectives}

The discovery of thermo TRP channels led researchers to develop the thermal manipulation of neural activities, called "thermogenetics" (Bernstein et al. 2012; Ermakova et al. 2020). Other temperature-sensing systems that are uncovered yet could have the potential to be key components of the next method of advanced thermal manipulations and thermal therapies.

To understand the mechanism of temperature-sensing systems in cells, approaches using reconstituted systems composed of purified proteins are sometimes appropriate (e.g., see Ishii et al. 2019). One-by-one reconstitution of components while examining the thermal response of the system allows examination of the contribution of each component directly. Computational methods are also effective to explain the interactions of multiple temperature-sensitive proteins. Shintani et al. reproduced HSOs in numerical simulation of sarcomere by hypothesizing on multiple temperature effects on thick and thin filaments (Shintani et al. 2020).

The flow of media induced by convection needs to be considered with caution in microheating experiments (Tseeb et al. 2009), as the flow may stimulate cells mechanically. To examine the effect of convection, we apply a similar or stronger flow of media to the cells as a control and confirm that no obvious responses are induced in the cells as in the heating (Oyama et al. 2015a). Minimizing convection is an alternative approach by reducing the height of the imaging chamber down to $\sim 10 \mu \mathrm{m}$, if allowed by the experimental design (Maeda et al. 2011). We also note that the temperature gradient causes a concentration gradient of biomolecules by the process known as thermophoresis or the Soret effect (Duhr and Braun 2006; Baaske et al. 2007; Budin et al. 2009; Fukuyama and Maeda 2020). Although thermophoresis has not been examined extensively in studies of cellular temperature-sensing, it is an attractive subject to reveal if and how thermophoresis is involved.

Cellular responses observed under the microscope may not represent those in tissues. On stiff basements such as glass, plastic, or other polymer-based dishes ( $>\mathrm{GPa}$ ), cellular morphology, gene and protein expression, and cellular functions such as migration differ from those on soft biomaterials that mimic soft tissues in vivo (1-1000 kPa) (van Helvert et al. 2018; Guimarães et al. 2020; Romani et al. 2021). Cells cultured on or within the soft biomaterials form unique multicellular 3D structures such as spheroids and organoids (Hofer and Lutolf 2021). Recently, Zhu et al. used star-shaped gold nanoparticles in MCF-7 tumor spheroid for heating and observed $\left[\mathrm{Ca}^{2+}\right]_{\mathrm{i}}$ increases in the targeted cells, followed by the propagation of $\mathrm{Ca}^{2+}$ waves to adjacent cells (Zhu et al. 2021).

Finally, there remains substantial room for the development of advanced optical heaters and thermometers. Intracellular thermometry reported $1{ }^{\circ} \mathrm{C}$ or greater local temperature gradients in both stimulated and non-stimulated cells at the organelle level, such as in nuclei (Okabe et al. 2012; Nakano et al. 2017) (see also Vu et al. 2021 for the controversial result), mitochondria (Okabe et al. 2012; Kiyonaka et al. 2013; Homma et al. 2015; Nakano et al. 2017; Huang et al. 2018, 2021; Chrétien et al. 2018, 2020; Savchuk et al. 2019; Di et al. 2021), and ER/SR (Kiyonaka et al. 2013; Arai et al. 2014; Itoh et al. 2016; Hou et al. 2017; Kriszt et al. 2017; Oyama et al. 2020). However, these experimental results largely contradict to the estimates based on the theories of macroscopic heat transfer, which expect the local temperature rises of the orders of $10^{-4}$ to $10^{-5}{ }^{\circ} \mathrm{C}$. For interested readers of this issue, we recommend Baffou et al.'s commentary (Baffou et al. 2014) and following communications (Kiyonaka et al. 2015; Suzuki et al. 2015; Baffou et al. 2015), a comprehensive discussion from both biological and physical viewpoints (Macherel et al. 2021), and our review article (Suzuki and Plakhotnik 2020). The issue is partially caused by the ambiguity in the physical parameters for intracellular heat diffusions. As demonstrated by the nanohybrids (Sotoma et al. 2021; Song et al. 2021), technological advances would provide further insights into the heterogeneous local heat transfer in more detail and how the heterogeneity is caused by, e.g., the intracellular architectures and their building blocks. Moreover, to reveal the physiological roles of intracellular temperature gradients (both spatial and temporal), methods of heating that can reproduce these local temperature gradients, or organelle-targeted nanoheaters, are desired. Simultaneous measurement of temperature and another parameter by a single probe will be a powerful approach to explore the heat-induced changes in the parameter. For instance, it was possible to measure the temperature sensitivity of the velocity of active transport directly in cells by the nanometry of individual luminescent nanothermometers (Oyama et al. 2012b). FNDs may be powerful probes for measuring multiple intracellular parameters such as electric and magnetic fields, $\mathrm{pH}$, and protein dynamics in addition to the temperature (Fujisaku et al. 2019; Barry et al. 2020; Igarashi et al. 2020). 
In this review, we introduced opto-thermal technologies and their applications for investigating cellular temperaturesensing. They have already been widely applied in the field of human, animal, and plant studies, and the number of studies is increasing. Ongoing advances of these technologies will reveal novel temperature-sensing systems and physiological significance of thermogenesis in cells and lead us to the development of advanced thermal therapies.

Funding This work was supported by the Japan Science and Technology Agency JPMJPR17P3 (to KO), by QST President's Strategic Grant (Exploratory Research) (to KO), by JSPS KAKENHI Grant Number 19H03198 (to KO and MS), by Foundation of Kinoshita Memorial Enterprise (to MS), and by the Human Frontier Science Program RGP0047/2018 (to MS).

\section{Declarations}

Ethics approval This article does not contain any studies with human participants or animals performed by any of the authors.

Conflict of interest The authors declare no competing interests.

Open Access This article is licensed under a Creative Commons Attribution 4.0 International License, which permits use, sharing, adaptation, distribution and reproduction in any medium or format, as long as you give appropriate credit to the original author(s) and the source, provide a link to the Creative Commons licence, and indicate if changes were made. The images or other third party material in this article are included in the article's Creative Commons licence, unless indicated otherwise in a credit line to the material. If material is not included in the article's Creative Commons licence and your intended use is not permitted by statutory regulation or exceeds the permitted use, you will need to obtain permission directly from the copyright holder. To view a copy of this licence, visit http://creativecommons.org/licenses/by/4.0/.

\section{References}

Arai S, Ferdinandus, Takeoka S et al (2015a) Micro-thermography in millimeter-scale animals by using orally-dosed fluorescent nanoparticle thermosensors. Analyst 140:7534-7539. https://doi.org/ $10.1039 / \mathrm{c} 5 \mathrm{an} 01287 \mathrm{~b}$

Arai S, Lee S-C, Zhai D et al (2014) A molecular fluorescent probe for targeted visualization of temperature at the endoplasmic reticulum. Sci Rep 4:6701. https://doi.org/10.1038/srep06701

Arai S, Suzuki M, Park S-J et al (2015b) Mitochondria-targeted fluorescent thermometer monitors intracellular temperature gradient. Chem Commun 51:8044-8047. https://doi.org/10.1039/ c5 $\mathrm{cc} 01088 \mathrm{~h}$

Baaske P, Weinert FM, Duhr S et al (2007) Extreme accumulation of nucleotides in simulated hydrothermal pore systems. Proc Natl Acad Sci U S A 104:9346-9351. https://doi.org/10.1073/pnas. 0609592104

Baffou G, Rigneault H, Marguet D, Jullien L (2014) A critique of methods for temperature imaging in single cells. Nat Methods 11:899-901. https://doi.org/10.1038/nmeth.3073

Baffou G, Rigneault H, Marguet D, Jullien L (2015) Reply to: "Validating subcellular thermal changes revealed by fluorescent thermosensors" and "The $10^{5}$ gap issue between calculation and measurement in single-cell thermometry." Nat Methods 12:803. https://doi.org/10.1038/nmeth.3552

Bahat A, Caplan SR, Eisenbach M (2012) Thermotaxis of human sperm cells in extraordinarily shallow temperature gradients over a wide range. PLoS ONE 7:e41915. https://doi.org/10.1371/journ al.pone. 0041915

Bahat A, Eisenbach M, Tur-Kaspa I (2005) Periovulatory increase in temperature difference within the rabbit oviduct. Hum Reprod 20:2118-2121. https://doi.org/10.1093/humrep/dei006

Bahat A, Tur-Kaspa I, Gakamsky A et al (2003) Thermotaxis of mammalian sperm cells: a potential navigation mechanism in the female genital tract. Nat Med 9:149-150. https://doi.org/10. 1038/nm0203-149

Barry JF, Schloss JM, Bauch E et al (2020) Sensitivity optimization for NV-diamond magnetometry. Rev Mod Phys 92:015004. https://doi.org/10.1103/RevModPhys.92.015004

Bazett HC, McGlone B (1927) Temperature gradients in the tissues in man. Am J Physiol 82:415-451. https://doi.org/10.1152/ ajplegacy.1927.82.2.415

Bernstein JG, Garrity PA, Boyden ES (2012) Optogenetics and thermogenetics: technologies for controlling the activity of targeted cells within intact neural circuits. Curr Opin Neurobiol 22:61-71. https://doi.org/10.1016/j.conb.2011.10.023

Berridge MJ, Bootman MD, Roderick HL (2003) Calcium signalling: dynamics, homeostasis and remodelling. Nat Rev Mol Cell Biol 4:517-529. https://doi.org/10.1038/nrm1155

Bers DM (2002) Cardiac excitation-contraction coupling. Nature 415:198-205. https://doi.org/10.1038/415198a

Black B, Vishwakarma V, Dhakal K et al (2016) Spatial temperature gradients guide axonal outgrowth. Sci Rep 6:29876. https://doi. org/10.1038/srep29876

Braun D, Libchaber A (2002) Trapping of DNA by thermophoretic depletion and convection. Phys Rev Lett 89:188103. https:// doi.org/10.1103/PhysRevLett.89.188103

Brites CDS, Lima PP, Silva NJO et al (2012) Thermometry at the nanoscale. Nanoscale 4:4799-4829. https://doi.org/10.1039/ c2nr30663h

Brunet NM, Mihajlović G, Aledealat K et al (2012) Micromechanical thermal assays of $\mathrm{Ca}^{2+}$-regulated thin-filament function and modulation by hypertrophic cardiomyopathy mutants of human cardiac troponin. J Biomed Biotechnol 2012:657523. https:// doi.org/10.1155/2012/657523

Budin I, Bruckner RJ, Szostak JW (2009) Formation of protocelllike vesicles in a thermal diffusion column. J Am Chem Soc 131:9628-9629. https://doi.org/10.1021/ja9029818

Chen R, Romero G, Christiansen MG et al (2015) Wireless magnetothermal deep brain stimulation. Science 347:1477-1480. https://doi.org/10.1126/science.1261821

Choi J, Zhou H, Landig R et al (2020) Probing and manipulating embryogenesis via nanoscale thermometry and temperature control. Proc Natl Acad Sci U S A 117:14636-14641. https:// doi.org/10.1073/pnas.1922730117

Chrétien D, Bénit P, Ha H et al (2018) Mitochondria are physiologically maintained at close to $50{ }^{\circ} \mathrm{C}$. PLOS Biol 16:e2003992. https://doi.org/10.1371/journal.pbio.2003992

Chrétien D, Bénit P, Leroy C et al (2020) Pitfalls in monitoring mitochondrial temperature using charged thermosensitive fluorophores. Chemosensors 8:124. https://doi.org/10.3390/chemo sensors 8040124

Daniel RM, Danson MJ (2013) Temperature and the catalytic activity of enzymes: a fresh understanding. FEBS Lett 587:2738-2743. https://doi.org/10.1016/j.febslet.2013.06.027

Di X, Wang D, Zhou J et al (2021) Quantitatively monitoring in situ mitochondrial thermal dynamics by upconversion 
nanoparticles. Nano Lett 21:1651-1658. https://doi.org/10. 1021/acs.nanolett.0c04281

Dittami GM, Rajguru SM, Lasher RA et al (2011) Intracellular calcium transients evoked by pulsed infrared radiation in neonatal cardiomyocytes. J Physiol 589:1295-1306. https://doi.org/10. 1113/jphysiol.2010.198804

Dode L, Van Baelen K, Wuytack F, Dean WL (2001) Low temperature molecular adaptation of the skeletal muscle sarco(endo) plasmic reticulum $\mathrm{Ca}^{2+}$-ATPase 1 (SERCA 1) in the wood frog (Rana sylvatica). J Biol Chem 276:3911-3919. https://doi.org/ 10.1074/jbc.M007719200

Duhr S, Braun D (2006) Why molecules move along a temperature gradient. Proc Natl Acad Sci U S A 103:19678-19682. https:// doi.org/10.1073/pnas.0603873103

Ebbesen CL, Bruus H (2012) Analysis of laser-induced heating in optical neuronal guidance. J Neurosci Methods 209:168-177. https:// doi.org/10.1016/j.jneumeth.2012.02.006

Elias M, Wieczorek G, Rosenne S, Tawfik DS (2014) The universality of enzymatic rate-temperature dependency. Trends Biochem Sci 39:1-7. https://doi.org/10.1016/j.tibs.2013.11.001

Eom K, Kim J, Choi JM et al (2014) Enhanced infrared neural stimulation using localized surface plasmon resonance of gold nanorods. Small 10:3853-3857. https://doi.org/10.1002/smll.201400599

Ermakova YG, Roshchin MV, Lanin AA et al (2020) Thermogenetics as a new direction in controlling the activity of neural networks. Neurosci Behav Physiol 50:1018-1023. https://doi.org/10.1007/ s11055-020-01001-1

Fedotov IV, Safronov NA, Ermakova YG et al (2015) Fiber-optic control and thermometry of single-cell thermosensation logic. Sci Rep 5:15737. https://doi.org/10.1038/srep15737

Ferdinandus Arai S, Takeoka S et al (2016) Facilely fabricated luminescent nanoparticle thermosensor for real-time microthermography in living animals. ACS Sensors 1:1222-1227. https://doi.org/10. 1021/acssensors.6b00320

Fujisaku T, Tanabe R, Onoda S et al (2019) pH nanosensor using electronic spins in diamond. ACS Nano 13:11726-11732. https://doi. org/10.1021/acsnano.9b05342

Fukuyama T, Maeda YT (2020) Opto-thermal diffusiophoresis of soft biological matter: from physical principle to molecular manipulation. Biophys Rev 12:309-315. https://doi.org/10.1007/ s12551-020-00692-7

Geeves MA, Lehrer SS, Lehman W (2019) The mechanism of thin filament regulation: models in conflict? J Gen Physiol 151:12651271. https://doi.org/10.1085/jgp.201912446

Genet S, Costalat R, Burger J (2000) A few comments on electrostatic interactions in cell physiology. Acta Biotheor 48:273-287. https://doi.org/10.1023/a:1010229531210

Gillis TE, Marshall CR, Xue XH et al (2000) $\mathrm{Ca}^{2+}$ binding to cardiac troponin $\mathrm{C}$ : effects of temperature and $\mathrm{pH}$ on mammalian and salmonid isoforms. Am J Physiol Regul Integr Comp Physiol 279:R1707-R1715. https://doi.org/10.1152/ajpregu.2000.279.5. R1707

Gobin AM, Lee MH, Halas NJ et al (2007) Near-infrared resonant nanoshells for combined optical imaging and photothermal cancer therapy. Nano Lett 7:1929-1934. https://doi.org/10.1021/ nl070610y

Goldman YE, McCray JA, Ranatunga KW (1987) Transient tension changes initiated by laser temperature jumps in rabbit psoas muscle fibres. J Physiol 392:71-95. https://doi.org/10.1113/jphysiol. 1987.sp016770

Guimarães CF, Gasperini L, Marques AP, Reis RL (2020) The stiffness of living tissues and its implications for tissue engineering. Nat Rev Mater 5:351-370. https://doi.org/10.1038/ s41578-019-0169-1
Highsmith S (1977) The effects of temperature and salts on myosin subfragment-1 and F-actin association. Arch Biochem Biophys 180:404-408. https://doi.org/10.1016/0003-9861(77)90054-6

Highsmith S (1978) Heavy meromyosin binds actin with negative cooperativity. Biochemistry 17:22-26. https://doi.org/10.1021/ bi00594a004

Hirsch SM, Sundaramoorthy S, Davies T et al (2018) FLIRT: fast local infrared thermogenetics for subcellular control of protein function. Nat Methods 15:921-923. https://doi.org/10.1038/ s41592-018-0168-y

Hofer M, Lutolf MP (2021) Engineering organoids. Nat Rev Mater 6:402-420. https://doi.org/10.1038/s41578-021-00279-y

Homma M, Takei Y, Murata A et al (2015) A ratiometric fluorescent molecular probe for visualization of mitochondrial temperature in living cells. Chem Commun 51:6194-6197. https://doi.org/ 10.1039/C4CC10349A

Hou Y, Arai S, Kitaguchi T, Suzuki M (2016) Intracellular bottom-up generation of targeted nanosensors for single-molecule imaging. Nanoscale 8:3218-3225. https://doi.org/10.1039/c5nr08012f

Hou Y, Kitaguchi T, Kriszt R et al (2017) $\mathrm{Ca}^{2+}$-associated triphasic $\mathrm{pH}$ changes in mitochondria during brown adipocyte activation. Mol Metab 6:797-808. https://doi.org/10.1016/j.molmet.2017.05.013

Huang H, Delikanli S, Zeng H et al (2010) Remote control of ion channels and neurons through magnetic-field heating of nanoparticles. Nat Nanotechnol 5:602-606. https://doi.org/10.1038/ nnano. 2010.125

Huang X, El-Sayed IH, Qian W, El-Sayed MA (2006) Cancer cell imaging and photothermal therapy in the near-infrared region by using gold nanorods. J Am Chem Soc 128:2115-2120. https:// doi.org/10.1021/ja057254a

Huang Z, Li N, Zhang X et al (2018) Fixable molecular thermometer for real-time visualization and quantification of mitochondrial temperature. Anal Chem 90:13953-13959. https://doi.org/10. 1021/acs.analchem.8b03395

Huang Z, Li N, Zhang X, Xiao Y (2021) Mitochondria-anchored molecular thermometer quantitatively monitoring cellular inflammations. Anal Chem 93:5081-5088. https://doi.org/10.1021/acs. analchem.0c04547

Igarashi R, Sugi T, Sotoma S et al (2020) Tracking the 3D rotational dynamics in nanoscopic biological systems. J Am Chem Soc 142:7542-7554. https://doi.org/10.1021/jacs.0c01191

Inoue T, Nakaoka Y (1990) Cold-sensitive responses in the Paramecium membrane. Cell Struct Funct 15:107-112. https://doi.org/ 10.1247/csf.15.107

Ishii S, Oyama K, Arai T et al (2019) Microscopic heat pulses activate cardiac thin filaments. J Gen Physiol 151:860-869. https://doi. org/10.1085/jgp.201812243

Ishii S, Oyama K, Shintani SA et al (2020) Thermal activation of thin filaments in striated muscle. Front Physiol 11:278. https://doi. org/10.3389/fphys.2020.00278

Ishiwata S (1978) Studies on the F-actin.tropomyosin.troponin complex. III. Effects of troponin components and calcium ion on the binding affinity between tropomyosin and F-actin. Biochim Biophys Acta 534:350-357. https://doi.org/10.1016/0005-2795(78) 90018-1

Ishizaka S (1969) Surface characters of dividing cells. III. Unequal division caused by steep temperature gradient in grasshopper spermatocyte. Dev Growth Differ 11:104-114. https://doi.org/ 10.1111/j.1440-169x.1969.00104.x

Itoh H, Arai S, Sudhaharan T et al (2016) Direct organelle thermometry with fluorescence lifetime imaging microscopy in single myotubes. Chem Commun 52:4458-4461. https://doi.org/10.1039/ C5CC09943A

Itoh H, Oyama K, Suzuki M, Ishiwata S (2014) Microscopic heat pulse-induced calcium dynamics in single WI-38 fibroblasts. 
BIOPHYSICS 10:109-119. https://doi.org/10.2142/biophysics. 10.109

Iwaki M, Iwane AH, Ikezaki K, Yanagida T (2015) Local heat activation of single myosins based on optical trapping of gold nanoparticles. Nano Lett 15:2456-2461. https://doi.org/10.1021/nl504 9059

Iwanaga S, Kaneko T, Fujita K et al (2006) Location-dependent photogeneration of calcium waves in HeLa cells. Cell Biochem Biophys 45:167-176. https://doi.org/10.1385/CBB:45:2:167

Jaque D, Vetrone F (2012) Luminescence nanothermometry. Nanoscale 4:4301-4326. https://doi.org/10.1039/c2nr30764b

Jenkins MW, Duke AR, Gu S et al (2010) Optical pacing of the embryonic heart. Nat Photonics 4:623-626. https://doi.org/10.1038/ nphoton.2010.166

Kam NWS, O'Connell M, Wisdom JA, Dai H (2005) Carbon nanotubes as multifunctional biological transporters and near-infrared agents for selective cancer cell destruction. Proc Natl Acad Sci U S A 102:11600-11605. https://doi.org/10.1073/pnas.0502680102

Kamei Y, Suzuki M, Watanabe K et al (2009) Infrared laser-mediated gene induction in targeted single cells in vivo. Nat Methods 6:79-81. https://doi.org/10.1038/nmeth.1278

Kato H, Nishizaka T, Iga T et al (1999) Imaging of thermal activation of actomyosin motors. Proc Natl Acad Sci U S A 96:9602-9606. https://doi.org/10.1073/pnas.96.17.9602

Kawaguchi K, Ishiwata S (2001) Thermal activation of single kinesin molecules with temperature pulse microscopy. Cell Motil Cytoskeleton 49:41-47. https://doi.org/10.1002/cm.1019

Kiyonaka S, Kajimoto T, Sakaguchi R et al (2013) Genetically encoded fluorescent thermosensors visualize subcellular thermoregulation in living cells. Nat Methods 10:1232-1238. https://doi.org/10. 1038/nmeth. 2690

Kiyonaka S, Sakaguchi R, Hamachi I et al (2015) Validating subcellular thermal changes revealed by fluorescent thermosensors. Nat Methods 12:801-802. https://doi.org/10.1038/nmeth.3548

Kremneva EV, Nikolaeva OP, Gusev NB et al (2003) Effects of troponin on thermal unfolding of actin-bound tropomyosin. Biochemistry (Moscow) 68:802-809. https://doi.org/10.1023/A: 1025043202615

Kriszt R, Arai S, Itoh H et al (2017) Optical visualisation of thermogenesis in stimulated single-cell brown adipocytes. Sci Rep 7:1383. https://doi.org/10.1038/s41598-017-00291-9

Kucsko G, Maurer PC, Yao NY et al (2013) Nanometre-scale thermometry in a living cell. Nature 500:54-58. https://doi.org/10. 1038/nature12373

Kurihara S, Sakai T (1985) Effects of rapid cooling on mechanical and electrical responses in ventricular muscle of guinea-pig. J Physiol 361:361-378. https://doi.org/10.1113/jphysiol.1985.sp015650

Landeira-Fernandez AM, Morrissette JM, Blank JM, Block BA (2004) Temperature dependence of the $\mathrm{Ca}^{2+}$-ATPase (SERCA2) in the ventricles of tuna and mackerel. Am J Physiol Regul Integr Comp Physiol 286:R398-R404. https://doi.org/10.1152/ajpregu.00392. 2003

Lehman W (2017) Switching muscles on and off in steps: the McKillop-Geeves three-state model of muscle regulation. Biophys $\mathbf{J}$ 112:2459-2466. https://doi.org/10.1016/j.bpj.2017.04.053

Liao J, Han R, Wu Y, Qian Z (2021) Review of a new bone tumor therapy strategy based on bifunctional biomaterials. Bone Res 9:18. https://doi.org/10.1038/s41413-021-00139-z

Liu Q, Frerck MJ, Holman HA et al (2014) Exciting cell membranes with a blustering heat shock. Biophys J 106:1570-1577. https:// doi.org/10.1016/j.bpj.2014.03.008

Liu Y, Cheng DK, Sonek GJ et al (1995) Evidence for localized cell heating induced by infrared optical tweezers. Biophys J 68:21372144. https://doi.org/10.1016/S0006-3495(95)80396-6
Loo C, Lowery A, Halas N et al (2005) Immunotargeted nanoshells for integrated cancer imaging and therapy. Nano Lett 5:709-711. https://doi.org/10.1021/n1050127s

Lumbreras V, Bas E, Gupta C, Rajguru SM (2014) Pulsed infrared radiation excites cultured neonatal spiral and vestibular ganglion neurons by modulating mitochondrial calcium cycling. J Neurophysiol 112:1246-1255. https://doi.org/10.1152/jn.00253.2014

Macherel D, Haraux F, Guillou H, Bourgeois O (2021) The conundrum of hot mitochondria. Biochim Biophys Acta - Bioenerg 1862:148348. https://doi.org/10.1016/j.bbabio.2020.148348

Maeda YT, Buguin A, Libchaber A (2011) Thermal separation: interplay between the Soret effect and entropic force gradient. Phys Rev Lett 107:038301. https://doi.org/10.1103/PhysRevLett.107. 038301

Marino A, Arai S, Hou Y et al (2017) Gold nanoshell-mediated remote myotube activation. ACS Nano 11:2494-2508. https://doi.org/10. 1021/acsnano.6b08202

Miller IC, Gamboa Castro M, Maenza J et al (2018) Remote control of mammalian cells with heat-triggered gene switches and photothermal pulse trains. ACS Synth Biol 7:1167-1173. https://doi. org/10.1021/acssynbio.7b00455

Miyako E, Deguchi T, Nakajima Y et al (2012a) Photothermic regulation of gene expression triggered by laser-induced carbon nanohorns. Proc Natl Acad Sci U S A 109:7523-7528. https:// doi.org/10.1073/pnas.1204391109

Miyako E, Kono K, Yuba E et al (2012b) Carbon nanotube-liposome supramolecular nanotrains for intelligent molecular-transport systems. Nat Commun 3:1226. https://doi.org/10.1038/ncomm s2233

Miyako E, Russier J, Mauro M et al (2014) Photofunctional nanomodulators for bioexcitation. Angew Chem Int Ed Engl 53:13121-13125. https://doi.org/10.1002/anie.201407169

Nagel-Volkmann J, Plieth C, Becker D et al (2009) Cold-induced cytosolic free calcium ion concentration changes in wheat. J Plant Physiol 166:1955-1960. https://doi.org/10.1016/j.jplph. 2009.05.002

Nakano M, Arai Y, Kotera I et al (2017) Genetically encoded ratiometric fluorescent thermometer with wide range and rapid response. PLoS ONE 12:e0172344. https://doi.org/10.1371/ journal.pone. 0172344

Nicklas RB (1973) Methods for gentle, differential heating of part of a single living cell. J Cell Biol 59:595-600. https://doi.org/ $10.1083 /$ jcb.59.3.595

Nicklas RB (1979) Chromosome movement and spindle birefringence in locally heated cells: interaction versus local control. Chromosoma 74:1-37. https://doi.org/10.1007/BF00344480

Okabe K, Inada N, Gota C et al (2012) Intracellular temperature mapping with a fluorescent polymeric thermometer and fluorescence lifetime imaging microscopy. Nat Commun 3:705. https://doi.org/10.1038/ncomms 1714

Okabe K, Sakaguchi R, Shi B, Kiyonaka S (2018) Intracellular thermometry with fluorescent sensors for thermal biology. Pflügers Arch - Eur J Physiol 470:717-731. https://doi.org/10.1007/ s00424-018-2113-4

Oyama K, Arai T, Isaka A et al (2015a) Directional bleb formation in spherical cells under temperature gradient. Biophys $\mathbf{J}$ 109:355-364. https://doi.org/10.1016/j.bpj.2015.06.016

Oyama K, Gotoh M, Hosaka Y et al (2020) Single-cell temperature mapping with fluorescent thermometer nanosheets. J Gen Physiol 152:e201912469. https://doi.org/10.1085/jgp.20191 2469

Oyama K, Mizuno A, Shintani SA et al (2012a) Microscopic heat pulses induce contraction of cardiomyocytes without calcium transients. Biochem Biophys Res Commun 417:607-612. https:// doi.org/10.1016/j.bbrc.2011.12.015 
Oyama K, Takabayashi M, Takei Y et al (2012b) Walking nanothermometers: spatiotemporal temperature measurement of transported acidic organelles in single living cells. Lab Chip 12:15911593. https://doi.org/10.1039/c2lc00014h

Oyama K, Zeeb V, Kawamura Y et al (2015b) Triggering of high-speed neurite outgrowth using an optical microheater. Sci Rep 5:16611. https://doi.org/10.1038/srep16611

Patapoutian A, Peier AM, Story GM, Viswanath V (2003) ThermoTRP channels and beyond: mechanisms of temperature sensation. Nat Rev Neurosci 4:529-539. https://doi.org/10.1038/nrn1141

Phillips CM, Mizutani Y, Hochstrasser RM (1995) Ultrafast thermally induced unfolding of RNase A. Proc Natl Acad Sci U S A 92:7292-7296. https://doi.org/10.1073/pnas.92.16.7292

Plaksin M, Kimmel E, Shoham S (2017) Correspondence: revisiting the theoretical cell membrane thermal capacitance response. Nat Commun 8:1431. https://doi.org/10.1038/s41467-017-00435-5

Plaksin M, Shapira E, Kimmel E, Shoham S (2018) Thermal transients excite neurons through universal intramembrane mechanoelectrical effects. Phys Rev X 8:11043. https://doi.org/10.1103/PhysR evX.8.011043

Plieth C, Hansen UP, Knight H, Knight MR (1999) Temperature sensing by plants: the primary characteristics of signal perception and calcium response. Plant J 18:491-497. https://doi.org/ 10.1046/j.1365-313X.1999.00471.x

Protasi F, Shtifman A, Julian FJ et al (2004) All three ryanodine receptor isoforms generate rapid cooling responses in muscle cells. Am J Physiol Cell Physiol 286:C662-C670. https://doi. org/10.1152/ajpcell.00081.2003

Rajan A, Sahu NK (2020) Review on magnetic nanoparticle-mediated hyperthermia for cancer therapy. J Nanoparticle Res 22:319. https://doi.org/10.1007/s11051-020-05045-9

Ranatunga KW (2018) Temperature effects on force and actin-myosin interaction in muscle: a look back on some experimental findings. Int J Mol Sci 19:1538. https://doi.org/10.3390/ijms1 9051538

Romani P, Valcarcel-Jimenez L, Frezza C, Dupont S (2021) Crosstalk between mechanotransduction and metabolism. Nat Rev Mol Cell Biol 22:22-38. https://doi.org/10.1038/ s41580-020-00306-w

Romshin AM, Zeeb V, Martyanov AK et al (2021) A new approach to precise mapping of local temperature fields in submicrometer aqueous volumes. Sci Rep 11:14228. https://doi.org/10.1038/ s41598-021-93374-7

Ross D, Gaitan M, Locascio LE (2001) Temperature measurement in microfluidic systems using a temperature-dependent fluorescent dye. Anal Chem 73:4117-4123. https://doi.org/10.1021/ac010 3701

Sakai T, Kurihara S (1974) A study on rapid cooling contracture from the viewpoint of excitation-contraction coupling. Jikei Med $\mathbf{J}$ 21:47-88

Savchuk OA, Silvestre OF, Adão RMR, Nieder JB (2019) GFP fluorescence peak fraction analysis based nanothermometer for the assessment of exothermal mitochondria activity in live cells. Sci Rep 9:7535. https://doi.org/10.1038/s41598-019-44023-7

Schwartz B, Feller MR (1962) Temperature gradients in the rabbit eye. Invest Ophthalmol 1:513-521

Shapiro MG, Homma K, Villarreal S et al (2012) Infrared light excites cells by changing their electrical capacitance. Nat Commun 3:736. https://doi.org/10.1038/ncomms 1742

Shintani SA, Oyama K, Fukuda N, Ishiwata S (2015) High-frequency sarcomeric auto-oscillations induced by heating in living neonatal cardiomyocytes of the rat. Biochem Biophys Res Commun 457:165-170. https://doi.org/10.1016/j.bbrc.2014.12.077

Shintani SA, Washio T, Higuchi H (2020) Mechanism of contraction rhythm homeostasis for hyperthermal sarcomeric oscillations of neonatal cardiomyocytes. Sci Rep 10:20468. https://doi.org/10. 1038/s41598-020-77443-x

Sitsapesan R, Montgomery RAP, Macleod KT et al (1991) Sheep cardiac sarcoplasmic reticulum calcium-release channels: modification of conductance and gating by temperature. J Physiol 434:469-488. https://doi.org/10.1113/jphysiol.1991.sp018481

Smith NI, Fujita K, Kaneko T et al (2001) Generation of calcium waves in living cells by pulsed-laser-induced photodisruption. Appl Phys Lett 79:1208-1210. https://doi.org/10.1063/1.1397255

Smith NI, Iwanaga S, Beppu T et al (2006) Photostimulation of two types of $\mathrm{Ca}^{2+}$ waves in rat pheochromocytoma PC12 cells by ultrashort pulsed near-infrared laser irradiation. Laser Phys Lett 3:154-161. https://doi.org/10.1002/lapl.200510067

Smith NI, Kumamoto Y, Iwanaga S et al (2008) A femtosecond laser pacemaker for heart muscle cells. Opt Express 16:8604-8616. https://doi.org/10.1364/OE.16.008604

Song P, Gao H, Gao Z et al (2021) Heat transfer and thermoregulation within single cells revealed by transient plasmonic imaging. Chem 7:1569-1587. https://doi.org/10.1016/j.chempr.2021.02. 027

Sotoma S, Zhong C, Kah JCY et al (2021) In situ measurements of intracellular thermal conductivity using heater-thermometer hybrid diamond nanosensors. Sci Adv 7:eabd7888. https://doi. org/10.1126/sciadv.abd7888

Stanley SA, Gagner JE, Damanpour S et al (2012) Radio-wave heating of iron oxide nanoparticles can regulate plasma glucose in mice. Science 336:604-608. https://doi.org/10.1126/science.1216753

Steel BC, McKenzie DR, Bilek MMM et al (2006) Nanosecond responses of proteins to ultra-high temperature pulses. Biophys J 91:L66-L68. https://doi.org/10.1529/biophysj.106.090944

Suzuki M, Arai S, Oyama K, Ishiwata S (2016) Nanothermometers: luminescent nanothermometers for biological applications. In: Kharisov BI, Kharissova OV, Ortiz-Mendez U (eds) CRC Concise Encyclopedia of Nanotechnology, 1st edn. CRC Press, pp 851-859

Suzuki M, Plakhotnik T (2020) The challenge of intracellular temperature. Biophys Rev 12:593-600. https://doi.org/10.1007/ s12551-020-00683-8

Suzuki M, Zeeb V, Arai S et al (2015) The $10^{5}$ gap issue between calculation and measurement in single-cell thermometry. Nat Methods 12:802-803. https://doi.org/10.1038/nmeth.3551

Takei Y, Arai S, Murata A et al (2014) A nanoparticle-based ratiometric and self-calibrated fluorescent thermometer for single living cells. ACS Nano 8:198-206. https://doi.org/10.1021/nn405456e

Talon S, Huchet-Cadiou C, Léoty C (2000) Rapid cooling-induced contractures in rat skinned skeletal muscle fibres originate from sarcoplasmic reticulum $\mathrm{Ca}^{2+}$ release through ryanodine and inositol trisphosphate receptors. Pflügers Arch - Eur J Physiol 441:108-117. https://doi.org/10.1007/s004240000375

Tsai P-C, Chen OY, Tzeng Y-K et al (2015) Gold/diamond nanohybrids for quantum sensing applications. EPJ Quantum Technol 2:19. https://doi.org/10.1140/epjqt/s40507-015-0031-3

Tsai P-C, Epperla CP, Huang J-S et al (2017) Measuring nanoscale thermostability of cell membranes with single gold-diamond nanohybrids. Angew Chem Int Ed Engl 56:3025-3030. https:// doi.org/10.1002/anie.201700357

Tseeb V, Suzuki M, Oyama K et al (2009) Highly thermosensitive $\mathrm{Ca}^{2+}$ dynamics in a HeLa cell through $\mathrm{IP}_{3}$ receptors. HFSP J 3:117-123. https://doi.org/10.2976/1.3073779

Uchiyama S, Matsumura Y, De SAP et al (2004) Modulation of the sensitive temperature range of fluorescent molecular thermometers based on thermoresponsive polymers. Anal Chem 76:1793-1798. https://doi.org/10.1021/ac035248w

van Helvert S, Storm C, Friedl P (2018) Mechanoreciprocity in cell migration. Nat Cell Biol 20:8-20. https://doi.org/10.1038/ s41556-017-0012-0 
Veltri T, de Oliveira GAP, Bienkiewicz EA et al (2017) Amide hydrogens reveal a temperature-dependent structural transition that enhances site-II $\mathrm{Ca}^{2+}$-binding affinity in a C-domain mutant of cardiac troponin C. Sci Rep 7:691. https://doi.org/10.1038/ s41598-017-00777-6

Vriens J, Nilius B, Voets T (2014) Peripheral thermosensation in mammals. Nat Rev Neurosci 15:573-589. https://doi.org/10.1038/ $\operatorname{nrn} 3784$

Vu CQ, Fukushima S, Wazawa T, Nagai T (2021) A highly-sensitive genetically encoded temperature indicator exploiting a temperature-responsive elastin-like polypeptide. Sci Rep 11:16519. https://doi.org/10.1038/s41598-021-96049-5

Weissleder R (2001) A clearer vision for in vivo imaging. Nat Biotechnol 19:316-317. https://doi.org/10.1038/86684

Wells J, Kao C, Konrad P et al (2007) Biophysical mechanisms of transient optical stimulation of peripheral nerve. Biophys J 93:25672580. https://doi.org/10.1529/biophysj.107.104786

Wells J, Kao C, Mariappan K et al (2005) Optical stimulation of neural tissue in vivo. Opt Lett 30:504-506. https://doi.org/10.1364/ol. 30.000504

Yong J, Needham K, Brown WGA et al (2014) Gold-nanorod-assisted near-infrared stimulation of primary auditory neurons. Adv Healthc Mater 3:1862-1868. https://doi.org/10.1002/adhm. 201400027
Yoo S, Hong S, Choi Y et al (2014) Photothermal inhibition of neural activity with near-infrared-sensitive nanotransducers. ACS Nano 8:8040-8049. https://doi.org/10.1021/nn5020775

Zeeb V, Suzuki M, Ishiwata S (2004) A novel method of thermal activation and temperature measurement in the microscopic region around single living cells. J Neurosci Methods 139:69-77. https://doi.org/10.1016/j.jneumeth.2004.04.010

Zhao Y, Kawai M (1994) Kinetic and thermodynamic studies of the cross-bridge cycle in rabbit psoas muscle fibers. Biophys $\mathrm{J}$ 67:1655-1668. https://doi.org/10.1016/S0006-3495(94)80638-1

Zhou J, del Rosal B, Jaque D et al (2020) Advances and challenges for fluorescence nanothermometry. Nat Methods 17:967-980. https://doi.org/10.1038/s41592-020-0957-y

Zhu D, Feng L, Feliu N et al (2021) Stimulation of local cytosolic calcium release by photothermal heating for studying intra- and intercellular calcium waves. Adv Mater 33:2008261. https://doi. org/10.1002/adma.202008261

Publisher's note Springer Nature remains neutral with regard to jurisdictional claims in published maps and institutional affiliations. 